Available online at: https://tsdr.psdku.unpad.ac.id/index.php/journal/index

Tourism and Sustainable Development Review Journal (TSDR)

ISSN 2722-2152 (online)

Volume 2 Number 2 (2021): 40-58

\title{
An Exploratory Study of the Gastronomic Use of Edible Flowers in Restaurant Menus: Basis for a Marketing Framework
}

\author{
Jesus N. Gamata, DBM-HM, CHP1', Antonino F. Alejandro, DBA ${ }^{1}$ \\ ${ }^{1}$ CBIBE, Philippine Women's University, Philippines
}

\begin{abstract}
Edible flowers have recorded several uses in local and international cuisines. The presence of these beautifully tasty and fragrant ingredients on restaurant menus becomes more common. In the Philippines, there was an evident research gap on the visibility and lack of available references or reviews affecting awareness of the gastronomic use of the edible flowers in the context of restaurant contemporary menus and cuisines. This exploratory study aimed to gather helpful details and information that can be useful in creating a strategic restaurant marketing framework. Data covered the evaluation and analysis of the marketing factors influencing consumers' behavior and the customers' actual experiences shared in the survey forming the primary data, including the inputs and knowledge shared by the restaurant experts and owners. Furthermore, the results of the study showed significant relationships between demographic profiles of respondents with the marketing factors influencing consumers, behavior and customers' experiences. There were also significant correlations, of different degrees, between the marketing factors influencing consumers' behavior and the customers' experiences. The definition of the relationships further resulted in the establishment of a restaurant marketing framework, wherein utilization of the strategic components was strongly recommended to sustain and promote edible flowers in the Philippine restaurant menus.
\end{abstract}

Keywords: Edible Flowers; Gastronomy; Gastronomic Use; Marketing Factors; Consumer Behavior; Customer Experiences; Marketing Framework

This is an open access article under the CC-BY-NC license.

\section{INTRODUCTION}

Gastronomy, culinary, and even cuisine could all refer to the study or the appreciation of food. At times, gastronomy is closely associated with culture, for it is incorporated in the new concept of cultural heritage (Gajic, 2015).

In ancient times, edible flowers seeds were transported like fine spices. This can be noted as means of how these flower-bearing plants started to spread around the globe. Flowers have been included in food as far back as we have records. Ancient Greek, Roman and Chinese herbalists recorded medicinal and culinary uses for flowers (Degman, 2017).

Corresponding author

Jesus N. Gamata, DBM-HM, CHP, chef.jngamata@gmail.com / jesus.gamata@global.edu.ph DOI: https://doi.org/10.31098/tsdr.v2i2.53 
Evidently, history shows that flower petals were eaten most often fresh in salads or as edible garnishes. In fact, chefs in Europe use edible flowers a lot in garnishing foods (Pam, 2011).

In various ways, people are turning the clock back to this trend of history. It is "overemphasized" at present due to its visibility in public through social media tools. People have a relatively increasing desire and interest in healthy living or lifestyle by introducing organic farming, considering local and home-grown fresh harvests. This point of interest amongst people has highlighted the use of edible flowers, but the focus of the present generation deals more with the aesthetic value it provides. However, technically speaking, these edible flowers aren't just for beauty; it is added to dishes beyond that purpose. Tying this culinary history into a larger cultural one, they show flowers' cultural, symbolic and religious connotations have added value and meaning to dishes in daily life and special occasions. The use of edible flowers as an aesthetic and flavour component of specific dishes is gaining popularity (D'Antuono and Manco, 2013).

Philippines, being an agricultural country, also grow edible flowers in selected regions. Apparently, there are no specific organizations that solely promote the use of edible flowers in the Philippines. The Cut Flower Industry, a journal of the Philippine Statistics Authority (Vol. 59 No.2, 2nd Quarter 2008), is focused on cut flowers or floriculture, specifically ornamental flowers. With these specific concerns mentioned, the researcher, who happens to be a culinary enthusiast, is driven by curiosity and genuine interest to explore and study the gastronomic use of edible flowers in restaurant menus. With the expected global market growth of edible flowers from 2019-2028, the researcher has been inspired to investigate the marketing and promotion of the use of edible flowers in the Philippines. This shall include collecting pieces of evidence and determining the marketing-related aspects or factors in the consumption of edible flowers as offered by restaurants in the Philippines.

The nature of this study is an examination of a subject in an attempt to gain further insight or information (Winston, 2017). This study will include the data and information supplemented by a face-to-face/written interview with the experts (restaurateurs/owners/ managers of the restaurant) with menu offerings that utilize edible flowers and from their diners/customers. Results of the said exploratory study shall be considered by the researcher in coming up with a marketing framework which deemed useful for restaurants offering and are planning to offer edible flower dishes in their menus.

\section{RESEARCH METHOD}

In order to provide an analysis on the status of the gastronomic use of edible flowers among restaurants offering edible flower dishes, the descriptive correlational research design was utilized combined with key informant interviews (KII) with restaurant owners or managers. Posted by Colson Steber (2018) in a market research blog, market researchers classify KII as a type of in-depth qualitative interview. This was applied during the researcher's interview with the restaurant owners or managers who were regarded as the source of experts' knowledge and opinions.

The researcher utilized the descriptive survey research design applying both observational and survey methods. Since this study included both quantitative and qualitative assessment, descriptive research was the appropriate design to be used. This design was used for gathering information about existing conditions to describe the essence of a situation as it exists at the time 
of the investigation. Further, correlation design was used to establish the relationship between factors (Andales, 2001).

As stated by Adi Bhat (2019) in QuestionPro, an online article, one of the advantages of descriptive research is that it is varied. Since the data collected were both qualitative and quantitative, it gave a holistic understanding of the research topic. This caused data that was not planned to be collected to get tracked, and the data were varied, diverse and thorough. In addition, this study was conducted to assess the status of the gastronomic use of edible flowers, marketing issues and other issues relevant to the consumption of edible flowers to come up with a useful marketing framework for restaurants.

The data and information needed in this study were gathered through the use of a semistructured questionnaire, following a hybrid of a qualitative topic guide and a quantitative questionnaire, wherein some questions were adopted and modified from the dissertation titled Encounters with Local Food: "The Culinary Experiences of International Visitors in Indonesia by Serli Wijaya (2014). Technically, it followed the qual-Quan combining model in research since the researcher employed both qualitative and quantitative measures. This study was guided by Research Framework in Figure 1.

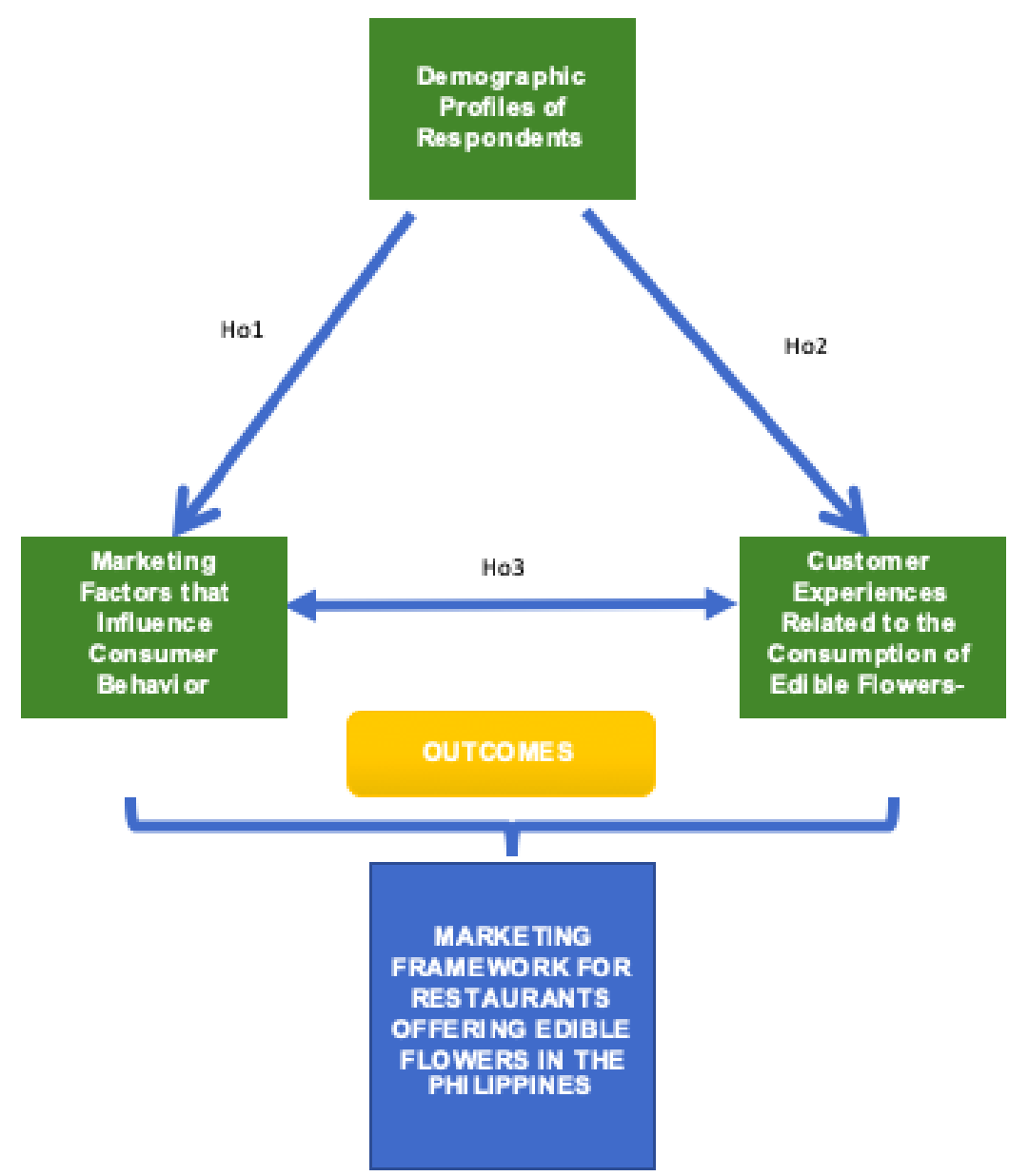

Figure 1. Research Framework 
A questionnaire checklist was adopted (Part II and III) with some modifications made to answer the specific objective of the study, while part I was developed by the researcher. The questionnaire checklist form consisted of three (3) parts: Part I of the survey deals with the profile of the customer-respondents. Part II dealt with the extent of affirmation on consumer behavior with subsets of questions which are grouped as preconceptions of customers, buying decision factors, and promotion and awareness. Part III was composed of customer experiences with criteria that have been grouped into 5 clusters, specifically, customer relationships and services, physical environment and ambience, product acceptability and issues, pricing standards and the place and accessibility.

\section{FINDINGS AND DISCUSSION}

\section{Demographic profiles of the respondents}

Respondents were actual diners of the five (5) restaurants involved in this research. They are diners with personal experiences that they have had consumed edible flower dishes at least once.

In summary, there were two hundred thirty-four (234) customer-respondents who participated in the study. When age is considered, results presented a greater percentage of the respondents occupy the middle group. Most of the customer-respondents were in the age range of 26 to 40 years old, with $48.72 \%$ of the total respondents. This age range is clustered as generation $\mathrm{Y}$, also known as the millennial's generation. This is congruent with the market research conducted by Andrews (2018) that millennials and generation Z spend more money eating out than any other generation, with $54 \%$ dining out at least three times a week.

In terms of gender, the majority of the respondents with $61.54 \%$, were females. The result of this profiling is supported by the study Bernabeu (2012), revealing women are more proactive in the consumption of organic foods to which edible flowers are classified. Furthermore, the study of Kelly, et al. (2018) showed that females were more likely to purchase edible flowers than males.

With regard to the highest educational attainment, the majority or $82.05 \%$ of the respondents have earned a diploma and bachelor's degrees with a total of 192 from the 234. Lastly, when it comes to monthly income, half of the target respondents or $50 \%$ of the customerrespondents were earning between $21,000 \mathrm{Php}$ to $30,000 \mathrm{Php}$.

The customer-respondents visiting profile revealed a variety of findings. Visiting profile includes the frequency of restaurants, the purpose of restaurant visits and travel party or companion during visits. The majority, or $70.94 \%$, have recorded $2-3$ previous visits, with about $67.95 \%$ corresponding to the purpose of "trying a specialty". The findings revealed that the majority of the customer-respondents are "returning customers."

In terms of travel party or companion, results showed that $46.15 \%$ of the customerrespondents visits the restaurants with a group or friends; $35.90 \%$ were alone and very low percentages for visiting as a couple and as family. Since the majority of the customer-respondents are millennials, being with a group of friends with the highest percentage result is further supported by the millennials restaurant dining trends, which stated that they view dining as a social event and prefer communal tables when eating out. Communal dining is something to think about when planning a restaurant and dining room (Mealey, 2018). 
Edible flowers as used by restaurants and are readily available in the Philippines

Restaurant experts also mentioned the specific edible flowers that they have had tried, currently being used in their menus and/or sold by their respective restaurants. The edible flowers include amaranth, arugula (wild), berry flower, blue pea/ternate, Cadena de Amor, chrysanthemum, cosmos, fennel, hibiscus/gumamela, impatiens, Saturday, nasturtium, purple coneflower, rose (fragrant), sage, Sampaguita, and snapdragon.

\section{EDIBLE FLOWERS USED BY RESTAURANTS}

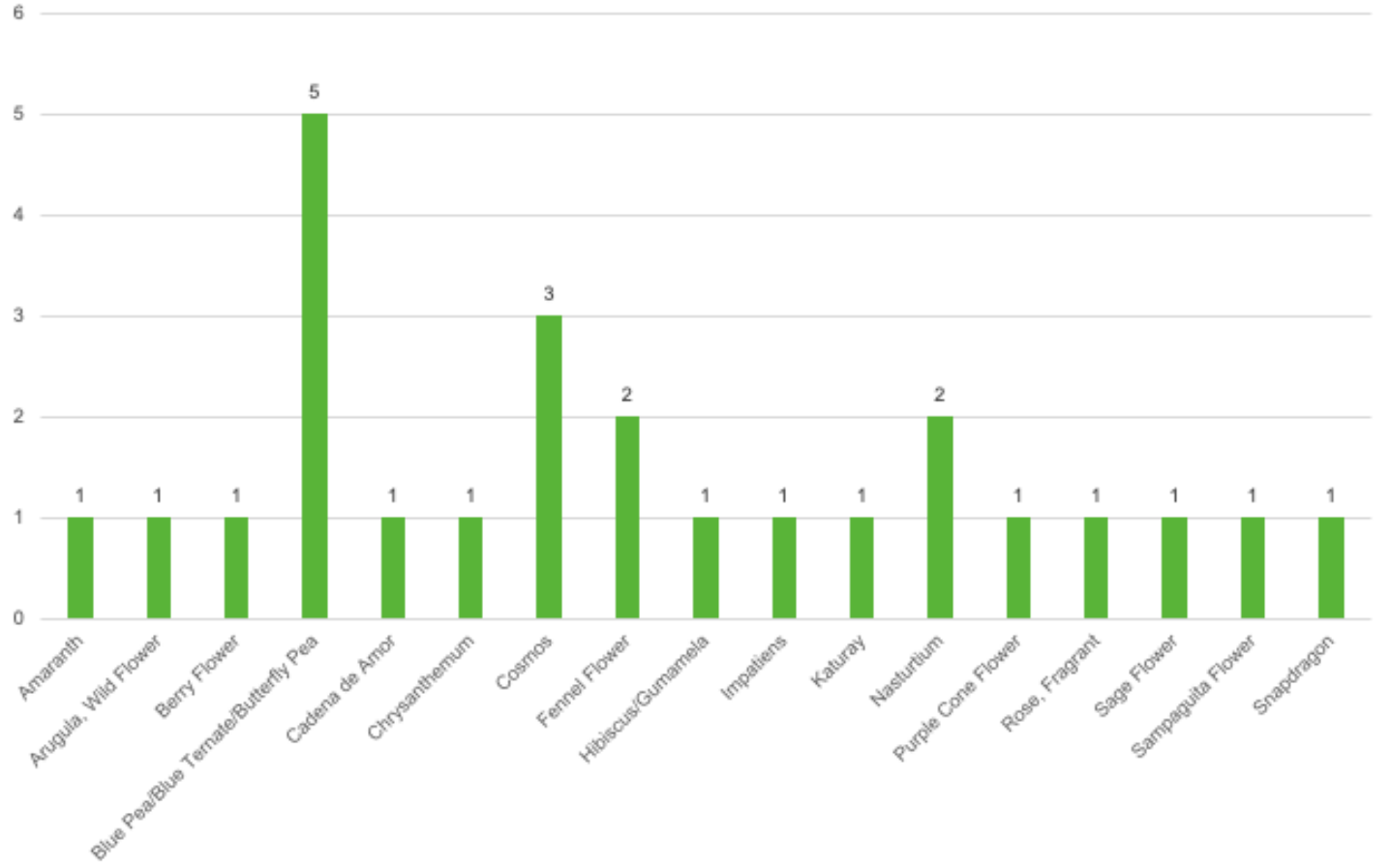

Figure 2. Edible Flowers Being Used by Restaurants and the Actual Number of Restaurants

\section{Results of Hypothesis determining the Relationship between the marketing factors that influence consumers' behavior with their demographic profiles}

Table 1. Relationship Between Age and Marketing Factors Influencing Consumers' Behavior

\begin{tabular}{|c|c|c|c|}
\hline Variables & Chi-Square Value & P-value & Interpretation \\
\hline Age Group and Preconceptions of Customers & 298.717 & 0.000 & Significant \\
\hline Age Group and Buying Decision Factors & 158.628 & 0.000 & Significant \\
\hline Age Group and Promotion and Awareness & 232.740 & 0.000 & Significant \\
\hline
\end{tabular}

Chi-square test results revealed that there was a significant relationship between age and the factors influencing consumer behavior. Since the composition of respondents in this study included different age generations, considering that every generation has its own characteristics, this signifies that generational cohorts have different expectations, experiences and perceptions, which can influence their values, preferences and purchasing behavior (Anders Parment, 2013). 
Tourism and Sustainable Development Review Journal (TSDR), Vol. 2 (2), 40-58

An Exploratory Study of the Gastronomic Use of Edible Flowers in Restaurant Menus: Basis for a Marketing Framework

Jesus N. Gamata, DBM-HM, CHP, Antonino F. Alejandro, DBA

Table 2. Relationship Between Gender and Marketing Factors Influencing Consumers' Behavior

\begin{tabular}{|c|c|c|c|}
\hline Variables & Chi-Square Value & P-value & Interpretation \\
\hline Gender and Preconceptions of Customers & 19.509 & 0.000 & Not Significant \\
\hline Gender and Buying Decision Factors & 16.166 & 0.000 & Not Significant \\
\hline Gender and Promotion and Awareness & 7.626 & 0.000 & Not Significant \\
\hline
\end{tabular}

Table 2 results showed that gender did not in any way differentiate the respondents' perceptions on the three areas of consumer behavior evaluation. This signified that both male and female customer-respondents shared the same perceptions on factors influencing consumer behavior.

However, Sengel (2015) argued that gender is an important factor influencing local food. And that, it should be taken into consideration while developing management strategies. For instance, males tend to be more loyal, and the findings proved that they solely go back to destinations to try local food, making food a travel motivation for males, and females are more concerned with collecting information before their trips accordingly. On the other hand, focusing on the gastronomic use of edible flowers, women are more proactive in the consumption of organic foods to which edible flowers are classified (Rodolfo Bernabeu, 2012), and a study showed that females were more likely to purchase edible flowers than males (Kathleen M. Kelly, et al., 2018).

Table 3. Relationship Between Highest Education Attained and Marketing Factors Influencing Consumers' Behavior

\begin{tabular}{|c|c|c|c|}
\hline Variables & $\begin{array}{c}\text { Chi-Square } \\
\text { Value }\end{array}$ & P-value & Interpretation \\
\hline $\begin{array}{c}\text { Highest Education Attained and Preconceptions } \\
\text { of Customers }\end{array}$ & 18.197 & 0.000 & Not Significant \\
\hline $\begin{array}{c}\text { Highest Education Attained and Buying } \\
\text { Decision Factors }\end{array}$ & 31.351 & 0.000 & Significant \\
\hline $\begin{array}{c}\text { Highest Education Attained and Promotion and } \\
\text { Awareness }\end{array}$ & 7.918 & 0.000 & Not Significant \\
\hline
\end{tabular}

A different result was observed in the case of the highest education attained when it comes to buying decision factors. Preconceptions and promotional influences resulted in not significant interpretations. Anhijeet Pratap (2019) confirmed this in his article, which mentioned that education affects the level of discretion they employ while making purchases, whereas the more educated a person is, the higher the level of discretion he will employ in deciding purchases.

Table 4. Relationship Between Monthly Income and Marketing Factors Influencing Consumers'

Behavior

\begin{tabular}{|c|c|c|c|}
\hline Variables & $\begin{array}{c}\text { Chi-Square } \\
\text { Value }\end{array}$ & P-value & Interpretation \\
\hline $\begin{array}{c}\text { Monthly Income and Preconceptions of } \\
\text { Customers }\end{array}$ & 62.537 & 0.000 & Significant \\
\hline
\end{tabular}

45 
Tourism and Sustainable Development Review Journal (TSDR), Vol. 2 (2), 40-58

An Exploratory Study of the Gastronomic Use of Edible Flowers in Restaurant Menus: Basis for a Marketing Framework

Jesus N. Gamata, DBM-HM, CHP, Antonino F. Alejandro, DBA

\begin{tabular}{|c|c|c|c|}
\hline Monthly Income and Buying Decision Factors & 28.549 & 0.000 & Not Significant \\
\hline Monthly Income and Promotion and Awareness & 36.274 & 0.000 & Significant \\
\hline
\end{tabular}

Although money or income directly affect the purchasing power, in this case, the spending habits of the majority of the customer-respondents were considered why it resulted to not significant in terms of the buying decision factors. In a documentary article authored by Rufino Rios (2017) published in PhilStar.com, millennials choose fun over financial responsibility and that this generation claimed that they deserved to use their income to enjoy life, not to mention travelling, went out to bars and restaurants. Since the majority $(77.35 \%)$ of the customerrespondents was participated by millennials (48.72\%) and generation Z (28.63\%), another observation that can support this is Andrews' (2018) survey which provided the relevant findings that millennials and generation $\mathrm{Z}$ spend more money eating out than any other generation.

Table 5. Relationship Between Frequency of Visit and Marketing Factors Influencing Consumers' Behavior

\begin{tabular}{|c|c|c|c|}
\hline Variables & $\begin{array}{c}\text { Chi-Square } \\
\text { Value }\end{array}$ & P-value & Interpretation \\
\hline $\begin{array}{c}\text { Frequency of Visit and Preconceptions of } \\
\text { Customers }\end{array}$ & 34.706 & 0.000 & Significant \\
\hline Frequency of Visit and Buying Decision Factors & 24.720 & 0.000 & Not Significant \\
\hline Frequency of Visit and Promotion and Awareness & 18.398 & 0.000 & Significant \\
\hline
\end{tabular}

It can be gleaned from Table 5 that frequency of visit and buying decision factors had no significant relationship. Since $70.94 \%$ of the customer-respondents answered that they've been visiting the restaurant about 2-3 times, this signifies their familiarity with the restaurants, which made the frequency of visits was no longer significant in the buying decision factor. Frequency of visit and its relationship to preconceptions, and promotion and awareness were relatively significant because these factors include an idea or opinion of the customer-respondents made before actually experiencing a certain restaurant, including the factors that can possibly influence them to visit the place.

Table 6. Relationship Between Purpose of Visit and Marketing Factors Influencing Consumers' Behavior

\begin{tabular}{|c|c|c|c|}
\hline Variables & $\begin{array}{c}\text { Chi-Square } \\
\text { Value }\end{array}$ & P-value & Interpretation \\
\hline $\begin{array}{c}\text { Purpose of Visit and Preconceptions of } \\
\text { Customers }\end{array}$ & 39.598 & 0.000 & Significant \\
\hline Purpose of Visit and Buying Decision Factors & 44.400 & 0.000 & Significant \\
\hline Purpose of Visit and Promotion and Awareness & 25.949 & 0.000 & Significant \\
\hline
\end{tabular}

The purpose of visiting a restaurant showed a significant relationship to consumer behavior. This can be linked to the purpose of visit, which resulted in the demographic profiles wherein 159 
out of 234 or $67.94 \%$ said that their purpose was to try specialties which signifies the willingness of the customer-respondents to explore or try more of what the restaurants can offer to them. Hence, the value of experience is highlighted in this case.

Table 7. Relationship Between Travel Party/Companion and Marketing Factors Influencing Consumers' Behavior

\begin{tabular}{|c|c|c|c|}
\hline Variables & $\begin{array}{c}\text { Chi-Square } \\
\text { Value }\end{array}$ & P-value & Interpretation \\
\hline $\begin{array}{c}\text { Travel Party/Companion and Preconceptions of } \\
\text { Customers }\end{array}$ & 39.598 & 0.000 & Significant \\
\hline $\begin{array}{c}\text { Travel Party/Companion and Buying Decision } \\
\text { Factors }\end{array}$ & 44.400 & 0.000 & Significant \\
\hline $\begin{array}{c}\text { Travel Party/Companion and Promotion and } \\
\text { Awareness }\end{array}$ & 25.949 & 0.000 & Significant \\
\hline \begin{tabular}{c} 
Awant \\
\hline
\end{tabular}
\end{tabular}

When travel party/companion's relationship to consumer behavior was considered, results in Table 19 showed significant relationships. Such signifies that travel party/companion, whether alone or in a group/circle of friends, had a significant connection to their preconceptions, buying decisions and influences they got from promotion and awareness.

\section{Results of hypothesis determining the relationship between customers' experiences with their demographic profiles}

Age and the elements under customer experiences showed a significant relationship. Reiterating Parment's (2013) consideration of differences in generation characteristics, this signifies that generational cohorts have different expectations, experiences and perceptions, which can influence their values, preferences and purchasing behavior.

Table 8. Relationship Between Age and Customers' Experiences

\begin{tabular}{|c|c|c|c|}
\hline Variables & $\begin{array}{c}\text { Chi-Square } \\
\text { Value }\end{array}$ & P-value & Interpretation \\
\hline $\begin{array}{c}\text { Age Group and Customer Relationships and } \\
\text { Services }\end{array}$ & 112.385 & 0.000 & Significant \\
\hline $\begin{array}{c}\text { Age Group and Physical Environment and } \\
\text { Ambience }\end{array}$ & 79.601 & 0.000 & Significant \\
\hline $\begin{array}{c}\text { Age Group and Product Acceptability and Issues } \\
\text { Age Group and Pricing Standards }\end{array}$ & 203.333 & 0.000 & Significant \\
\hline Age Group and Place and Accessibility & 148.718 & 0.000 & Significant \\
\hline
\end{tabular}


Tourism and Sustainable Development Review Journal (TSDR), Vol. 2 (2), 40-58

An Exploratory Study of the Gastronomic Use of Edible Flowers in Restaurant Menus: Basis for a Marketing Framework

Jesus N. Gamata, DBM-HM, CHP, Antonino F. Alejandro, DBA

Table 9. Relationship Between Gender and Customers' Experiences

\begin{tabular}{|c|c|c|c|}
\hline Variables & $\begin{array}{c}\text { Chi-Square } \\
\text { Value }\end{array}$ & P-value & Interpretation \\
\hline Gender and Customer Relationships and Services & 3.765 & 0.957 & Not Significant \\
\hline $\begin{array}{c}\text { Gender and Physical Environment and } \\
\text { Ambience }\end{array}$ & 2.586 & 0.629 & Not Significant \\
\hline Gender and Product Acceptability and Issues & 29.421 & 0.133 & Not Significant \\
\hline Gender and Pricing Standards & 13.926 & 0.084 & Not Significant \\
\hline Gender and Place and Accessibility & 10.492 & 0.398 & Not Significant \\
\hline
\end{tabular}

Table 9 showed that gender had no significant relationship with customer experiences. This signifies that gender doesn't necessarily show a significant effect in assessing customer experiences. Both male and female shared common evaluations for the level of satisfaction and dissatisfaction based on their personal experiences and not based on their gender. For example, a good service provided by the restaurant can equally be perceived and assessed as good regardless of gender.

Table 10. Relationship Between Highest Education Attained and Customers' Experiences

\begin{tabular}{|c|c|c|c|}
\hline Variables & $\begin{array}{c}\text { Chi-Square } \\
\text { Value }\end{array}$ & P-value & Interpretation \\
\hline $\begin{array}{c}\text { Higher Education Attained and Customer } \\
\text { Relationships and Services }\end{array}$ & 12.611 & 0.246 & Not Significant \\
\hline $\begin{array}{c}\text { Higher Education Attained and Physical } \\
\text { Environment and Ambience }\end{array}$ & 3.471 & 0.482 & Not Significant \\
\hline $\begin{array}{c}\text { Higher Education Attained and Product } \\
\text { Acceptability and Issues }\end{array}$ & 15.207 & 0.853 & Not Significant \\
\hline Higher Education Attained and Pricing Standards & 8.050 & 0.429 & Not Significant \\
\hline $\begin{array}{c}\text { Higher Education Attained and Place and } \\
\text { Accessibility }\end{array}$ & 16.918 & 0.076 & Not Significant \\
\hline
\end{tabular}

Results in general for the relationship between education and customer experiences revealed were not significant. This, in effect, concludes that educational level was not significantly related to how customer-respondents evaluate their experiences. Regardless of education attained, bad customer service and products provide a negative impact to customers, while good or exemplary customer service and products reflect a positive impact on customers.

Table 11. Relationship Between Monthly Income and Customers' Experiences

\begin{tabular}{|c|c|c|c|}
\hline Variables & $\begin{array}{c}\text { Chi-Square } \\
\text { Value }\end{array}$ & P-value & Interpretation \\
\hline $\begin{array}{c}\text { Monthly Income and Customer Relationships and } \\
\text { Services }\end{array}$ & 19.161 & 0.511 & Not Significant \\
\hline
\end{tabular}


Tourism and Sustainable Development Review Journal (TSDR), Vol. 2 (2), 40-58

An Exploratory Study of the Gastronomic Use of Edible Flowers in Restaurant Menus: Basis for a Marketing Framework

Jesus N. Gamata, DBM-HM, CHP, Antonino F. Alejandro, DBA

\begin{tabular}{|c|c|c|c|}
\hline $\begin{array}{c}\text { Monthly Income and Physical Environment and } \\
\text { Ambience }\end{array}$ & 12.813 & 0.118 & Not Significant \\
\hline $\begin{array}{c}\text { Monthly Income and Product Acceptability and } \\
\text { Issues }\end{array}$ & 43.105 & 0.510 & Not Significant \\
\hline Monthly Income and Pricing Standards & 30.999 & 0.013 & Not Significant \\
\hline Monthly Income Place and Accessibility & 17.094 & 0.647 & Not Significant \\
\hline
\end{tabular}

Results showed that there was no significant relationship between income and how customer-respondents evaluate elements or factors related to customer experiences. This signified that sharing customer experience was not defined by income; a horrible experience remains equally horrible for customers regardless of their income levels.

Table 12. Relationship Between Frequency of Visit and Customers' Experiences

\begin{tabular}{|c|c|c|c|}
\hline Variables & $\begin{array}{c}\text { Chi-Square } \\
\text { Value }\end{array}$ & P-value & Interpretation \\
\hline $\begin{array}{c}\text { Frequency of Visit and Customer Relationships } \\
\text { and Services }\end{array}$ & 29.390 & 0.001 & Significant \\
\hline $\begin{array}{c}\text { Frequency of Visit and Physical Environment } \\
\text { and Ambience }\end{array}$ & 7.117 & 0.130 & Not Significant \\
\hline $\begin{array}{c}\text { Frequency of Visit and Product Acceptability and } \\
\text { Issues }\end{array}$ & 27.127 & 0.206 & Not Significant \\
\hline Frequency of Visit and Pricing Standards & 7.367 & 0.498 & Not Significant \\
\hline Frequency of Visit Place and Accessibility & 14.811 & 0.139 & Not Significant \\
\hline
\end{tabular}

All factors under customers' experience showed a result of not significant except for customer relationships and services, which resulted in having a significant relationship with the frequency of visit. This, in effect, concluded that frequency of visit had a significant comparative effect in assessing the customer relationships and services provided by restaurants such as experiences on communication channels, the responsiveness on online platforms, discount or reward systems, responsiveness and competence of staff and on how loyal customers were treated. Customer-respondents strongly agreed, as per the mean rating, that loyal customers are given VIP treatment.

Table 13. Relationship Between Purpose of Visit and Customers' Experiences

\begin{tabular}{|c|c|c|c|}
\hline Variables & $\begin{array}{c}\text { Chi-Square } \\
\text { Value }\end{array}$ & P-value & Interpretation \\
\hline $\begin{array}{c}\text { Purpose of Visit and Customer Relationships and } \\
\text { Services }\end{array}$ & 10.026 & 0.438 & Not Significant \\
\hline $\begin{array}{c}\text { Purpose of Visit and Physical Environment and } \\
\text { Ambience }\end{array}$ & 5.216 & 0.266 & Not Significant \\
\hline $\begin{array}{c}\text { Purpose of Visit and Product Acceptability and } \\
\text { Issues }\end{array}$ & 38.580 & 0.016 & Significant \\
\hline
\end{tabular}


Tourism and Sustainable Development Review Journal (TSDR), Vol. 2 (2), 40-58

An Exploratory Study of the Gastronomic Use of Edible Flowers in Restaurant Menus: Basis for a Marketing Framework

Jesus N. Gamata, DBM-HM, CHP, Antonino F. Alejandro, DBA

\begin{tabular}{|c|c|c|c|}
\hline Purpose of Visit and Pricing Standards & 14.758 & 0.064 & Not Significant \\
\hline Purpose of Visit Place and Accessibility & 23.545 & 0.009 & Significant \\
\hline
\end{tabular}

Different results were observed for product acceptability and issues and that of place and acceptability. Recalled from the result of purpose of visit, majority visited restaurants to try specialties which indicates that visiting the restaurant had a significant relationship on how customer-respondents evaluated product acceptability and issues. The same effect reflected on place and accessibility or on how products get distributed or delivered to the customers since $100 \%$ of the customer-respondents said that personal visit to the restaurant was their main access to edible flower dishes, which supported the claim that there is a significant and notable relationship with the purpose of visit.

Table 14. Relationship Between Travel Party/Companion and Customers' Experiences

\begin{tabular}{|c|c|c|c|}
\hline Variables & $\begin{array}{c}\text { Chi-Square } \\
\text { Value }\end{array}$ & P-value & Interpretation \\
\hline $\begin{array}{c}\text { Travel Party/Companion and Customer } \\
\text { Relationships and Services }\end{array}$ & 143.334 & 0.000 & Significant \\
\hline $\begin{array}{c}\text { Travel Party/Companion and Physical } \\
\text { Environment and Ambience }\end{array}$ & 10.569 & 0.103 & Not Significant \\
\hline $\begin{array}{c}\text { Travel Party/Companion and Product } \\
\text { Acceptability and Issues }\end{array}$ & 49.724 & 0.031 & Significant \\
\hline Travel Party/Companion and Pricing Standards & 64.503 & 0.000 & Significant \\
\hline Travel Party/Companion Place and Accessibility & 55.143 & 0.000 & Significant \\
\hline
\end{tabular}

Based on the results, there was no statistically significant relationship between customers' experience (physical environment and ambience) with their demographic profile. This resulted in accepting the null hypothesis (Ho2). It can be observed that this was the only variable or item that was interpreted as not significant. Since travel parties, as per the survey, resulting in group/friends, it can be assumed that the value of communal dining as mentioned in Table 4 interpretations was highlighted. This dining concept was more prioritized than dining ambience converting attention to feel happy and satisfied (Dunbar, 2017).

\section{Results of the hypothesis determining the correlation between factors of consumer behavior and customers' experiences in the gastronomic use of edible flowers}

For Ho3, Pearson Correlation Coefficient was used to determine the correlation between the factors of consumer behavior and customers' experiences in the gastronomic use of edible flowers. Pearson's correlation coefficient is the test statistics that measures the statistical relationship, or association, between two continuous variables. It is known as the best method of measuring the association between variables of interest because it is based on the method of covariance. It gives information about the magnitude of the association, or correlation, as well as the direction of the relationship. 
Tourism and Sustainable Development Review Journal (TSDR), Vol. 2 (2), 40-58

An Exploratory Study of the Gastronomic Use of Edible Flowers in Restaurant Menus: Basis for a Marketing Framework

Jesus N. Gamata, DBM-HM, CHP, Antonino F. Alejandro, DBA

Table 15. Correlation Between Preconceptions of Customers and Customers' Experiences

\begin{tabular}{|c|c|c|c|}
\hline Variables & $\begin{array}{c}\text { Chi-Square } \\
\text { Value }\end{array}$ & P-value & Interpretation \\
\hline $\begin{array}{c}\text { Preconceptions of Customers and Customer } \\
\text { Relationships and Services }\end{array}$ & 0.480 & 0.000 & Significant \\
\hline $\begin{array}{c}\text { Preconceptions of Customers and Physical } \\
\text { Environment and Ambience }\end{array}$ & 0.588 & 0.103 & Significant \\
\hline $\begin{array}{c}\text { Preconceptions of Customers and Product } \\
\text { Acceptability and Issues }\end{array}$ & 0.410 & 0.031 & Significant \\
\hline $\begin{array}{c}\text { Preconceptions of Customers and Pricing } \\
\text { Standards }\end{array}$ & 0.232 & 0.000 & Significant \\
\hline $\begin{array}{c}\text { Preconceptions of Customers Place and } \\
\text { Accessibility }\end{array}$ & 0.019 & 0.019 & Significant \\
\hline
\end{tabular}

Correlation between preconceptions and customer experiences showed significant correlation at different magnitude or degrees, which therefore connotes the significant association and effect between the variable or factors of the two areas. These factors were therefore considered in the proposed marketing framework.

As shown in the correlation results of Table 16, only one (1) item provided an insignificant correlation which fell under the correlation of buying decision factors and customer relationships and services. It can be noted that customer relationships and services are focused on elements that can be assessed through actual or first-hand experience and by repeat customers. Since the majority of $70.94 \%$ of the customer respondents are repeat customers, this indicates that they don't focus much anymore on the customer relationships and services factors; however, the reviews provided by the repeat customers can significantly affect the buying decision process for firsttimers. Iula-Cristina Vita (2020) confirmed this because reviews ranked 1st in the 6 factors influencing customer buying decisions. She specifically cited the research findings of Spiegel Research center (2017) that $95 \%$ of shoppers/buyers read online reviews before making a purchase, which makes reviews a powerful form of consumer engagement.

If you go over the Customer experiences elements in the questionnaire, it can be observed that the factors included in the assessment criteria are customer relationships and services, physical environment and ambience, product acceptability and issues, price standards and place or accessibility. Of these factors, 4 components or 4Ps of the marketing mix (physical, product, price and place) were strategically being measured, and only customer relationships and services, amongst others, focused on aftersales activities.

Table 16. Correlation Between Buying Decision Factors and customers' Experiences

\begin{tabular}{|c|c|c|c|}
\hline Variables & $\begin{array}{c}\text { Chi-Square } \\
\text { Value }\end{array}$ & P-value & Interpretation \\
\hline $\begin{array}{c}\text { Buying Decision Factors and Customer } \\
\text { Relationships and Services }\end{array}$ & -0.045 & 0.000 & Not Significant \\
\hline
\end{tabular}


Tourism and Sustainable Development Review Journal (TSDR), Vol. 2 (2), 40-58

An Exploratory Study of the Gastronomic Use of Edible Flowers in Restaurant Menus: Basis for a Marketing Framework

Jesus N. Gamata, DBM-HM, CHP, Antonino F. Alejandro, DBA

\begin{tabular}{|c|c|c|c|}
\hline $\begin{array}{c}\text { Buying Decision Factors and Physical } \\
\text { Environment and Ambience }\end{array}$ & -0.310 & 0.103 & Significant \\
\hline $\begin{array}{c}\text { Buying Decision Factors and Product } \\
\text { Acceptability and Issues }\end{array}$ & -0.568 & 0.031 & Significant \\
\hline Buying Decision Factors and Pricing Standards & 0.406 & 0.000 & Significant \\
\hline Buying Decision Factors and Accessibility & 0.197 & 0.019 & Significant \\
\hline
\end{tabular}

Table 17. Correlation Between Promotion and Awareness and Customers 'Experiences

\begin{tabular}{|c|c|c|c|}
\hline Variables & $\begin{array}{c}\text { Chi-Square } \\
\text { Value }\end{array}$ & P-value & Interpretation \\
\hline $\begin{array}{c}\text { Promotion and Awareness and Customer } \\
\text { Relationships and Services }\end{array}$ & -0.024 & 0.713 & Not Significant \\
\hline $\begin{array}{c}\text { Promotion and Awareness and Physical } \\
\text { Environment and Ambience }\end{array}$ & 0.623 & 0.000 & Significant \\
\hline $\begin{array}{c}\text { Promotion and Awareness and Product } \\
\text { Acceptability and Issues }\end{array}$ & 0.563 & 0.000 & Significant \\
\hline Promotion and Awareness and Pricing Standards & 0.099 & 0.132 & Not Significant \\
\hline Promotion and Awareness and Accessibility & -0.222 & 0.001 & Significant \\
\hline
\end{tabular}

Prior to formulating the marketing framework for restaurants offering edible flower dishes, the researcher opted to subject the two major areas (consumer behavior and customer experience) of customer respondents' evaluation to Pearson Correlation to assess and measure the magnitude of the association, or correlation, as well as the direction of their relationships which were presented in the aforementioned discussions. Areas with significant, whether strong, moderate or weak correlations, both negative and positive, were considered in the marketing framework being proposed by the researcher.

Results presented in Tables 15, 16 and 17 provided significant relationships on variables assessed by the customer-respondents, except for the correlation results of (1)buying decision factors and customer relationships and services with a very weak, negative correlation; (2)promotion and awareness and customer relationships and services with a very weak, negative correlation; and (3)promotion and awareness and pricing standards with a very weak, positive correlation. Hence, overall, the third presented null hypothesis is still rejected.

Furthermore, these results provided the direction and components of the proposed marketing framework that can be used by the restaurants offering edible flower dishes.

\section{Discussion}

Findings of the study showed that the demographic profiles of the respondents were: mostly from age ranging from 26 to 40 years old, male and were repeat customers of the restaurants.

There were seventeen edible flowers identified by the restaurant representatives which are being used by their restaurants. However, only one of the seventeen flowers resulted as the common edible flowers being used by the restaurants, and the flower is known as the blue pea (also 
Tourism and Sustainable Development Review Journal (TSDR), Vol. 2 (2), 40-58

An Exploratory Study of the Gastronomic Use of Edible Flowers in Restaurant Menus: Basis for a Marketing Framework

Jesus N. Gamata, DBM-HM, CHP, Antonino F. Alejandro, DBA

called blue ternate or butterfly pea); three restaurants are using cosmos, and two restaurants are using both fennel and nasturtium flowers.

For issues and concerns associated with the consumption of edible flowers as offered by restaurants, there was a low percentage of harm or risk and health-related issues associated with edible flowers' consumption, except for the presence of pests, insects or worms, which were possible results of the organic farming methods used to grow and produce edible flowers. Digital marketing tools such as social media platforms (facebook, instagram, etc.), official websites and blogs/vlogs were identified by the customer-respondents as the main and major marketing or advertising tools used by restaurants that linked them to the restaurants offering edible flower dishes. Being unfamiliar with the edible flowers and unsure about flowers' edibility were both main reasons why customer-respondents didn't like to eat or try a particular edible flower. Used in salads and as a garnish was the gastronomic use of edible flowers as assessed by the customerrespondents.

The marketing factors that influence consumer behavior in the gastronomic use of edible flowers in restaurants was based on the perception of the customer-respondents; preconceptions of customers resulted in an overall rating of 4.04 or agree, an overall rating of 4.04 or agree on rating for buying decision factors, while promotion and awareness received an overall rating of 4.55 or strongly agree. Most of the customer-respondents shared their knowledge regarding the health benefits of consuming edible flowers, which resulted in at least 147 of the 234 customerrespondents believed that edible flowers are rich in vitamins, followed by antioxidants for 135 , and 66 for natural flavors and color. In terms of frequency of consumption, mostly were consuming edible flowers occasionally. Most of the customer-respondents were link to the restaurants through the following marketing/advertising tools; 229 out of 234 answered social media, followed by 217 for vlogs/blogs, and 166 through official websites.

For the customers' experiences related to the consumption of edible flowers in restaurants; customer relationships and services received an overall rating of 4.18 or agree, the physical environment and ambience with an overall rating of 4.97 or strongly agree while 4.48 or strongly agree was the overall rating for product acceptability and issues. For pricing standards, it resulted in an overall rating of 3.64 or agree and 3.04 or neither agree nor disagree rating for place and accessibility.

When customer-respondents were asked regarding their experiences on the risks/harms associated with the consumption of edible flower dishes, the majority said that they had none, while 18 out of 234 disclosed their experience of having pests/insects/worms in their plates. All of them did not experience any health-related issues associated with the consumption of edible flowers. Collating the result regarding the edible flowers they have tried or tasted, it resulted in a total of eighteen edible flowers wherein all of them have had tried blue pea (also known as blue ternate or butterfly pea), 228 for squash blossom, 216 for banana blossom, followed by Saturday with 196, alokon with 118, and hibiscus or gumamela with 116. Of the 234 customer-respondents, 177 said that they are not willing to eat nor try a new edible flower because they are unsure about the edibility, followed by unfamiliar with the flower with 140, and 93 for the unfamiliar with the taste. 
Customer-respondents were also asked regarding their knowledge of the gastronomic uses of edible flowers; all of them answered that edible flowers are both used as salads and as an edible garnish. A relatively high-frequency count (213) also resulted in edible flowers' as used in dessert.

The relationship between the marketing factors that influence consumers' behavior with their demographic profiles was also measured. Age resulted in having a significant relationship to all of the factors/elements of consumer behavior which rejected the Ho1, while between gender and consumer behavior, it resulted in a not significant relationship that accepted the Ho1. For education attained and consumer behavior relationship, two areas (preconceptions and promotions) resulted to not significant which accepted the Ho1 while one area, specifically on buying decision factor, resulted to a significant relationship, rejecting the Ho1. Significant relationships between income and two areas of consumer behaviors (preconceptions and promotion) were recorded, which rejected the Ho1. For frequency of visit and consumer behavior relationship, two areas (preconceptions and promotions) resulted in significant relationships, rejecting Ho1, while one area, specifically on buying decision factor, resulted in a not significant relationship which accepted the Ho1. Both purposes of visit and travel party/companion elements resulted in significant relationships with the three areas of consumer behavior which means that these areas rejected the Ho1.

This study also assessed the relationship between customer experiences and the customerrespondents' demographic profiles. Age recorded significant relationships with the different criteria of customer experiences which rejected the Ho2. There were no significant relationships between the demographic profiles, gender, education attained and income to that of the customer experiences' factors, which all resulted in accepting the Ho2. For the relationship between frequency of visit and the five factors under customers' experiences, only one (customer relationship and services) factor resulted in a significant relationship that rejected the Ho2, while the four other factors accepted the Ho2.

As to the relationship between the purpose of visit and the five factors of customers' experiences, two factors (product acceptability and issues, and place and accessibility) resulted to a significant relationship rejecting the Ho2, while the three other factors accepted the Ho2. On the other hand, for travel party/companion and customers' experiences relationship, four of the five factors resulted in significant relationships rejecting the Ho2; while one factor (physical environment and ambience) resulted in a not significant relationship which accepted the Ho2.

The correlation between and among the factors or variables of consumers' behavior (preconceptions, buying decision factors, and promotion and awareness) and the customers' experiences (customer relationships and services, physical environment and ambience, product acceptability and issues, pricing standards, and place and accessibility) in the gastronomic use of edible flowers were also measured to come up with the information about the magnitude of the association, or correlation, as well as the direction of the relationships.

The correlation results for the preconceptions and the five factors/variables of customers' experiences were; all showed significant correlations, however with different degrees, such as significant positive moderate correlation between preconceptions and the three different factors/variables of customers' experiences ([1] customer relationships and services, [2] physical environment and ambience, and [3] product acceptability and issues), a significant positive weak 
correlation for pricing standards, while the significant negative weak correlation for place and accessibility.

For the correlation between buying decision factors and the customers' experiences, results showed different degrees of significant correlations for the four factors of customers' experiences, while only one factor (customer relationships and services) resulted in a not statistically significant negative weak correlation.

Two factors/variables of the customers' experiences resulted in a statistically not significant correlation to promotion and awareness, while three other factors resulted in significant correlations wherein one resulted in a strong positive correlation (physical environment and ambience).

There is a potential market growth for edible flowers; however, the following challenges or issues need to be considered:

a. lack of support from the LGU and/or government agencies;

b. lack of education about edible flowers;

c. seasonality of flowers, and lastly; and

d. transport logistics for supply and distribution.

\section{CONCLUSION}

The following conclusions were drawn based on the findings of the study. There are customer demographics that are found useful and should be considered in the restaurant business operation. It includes the age, purpose of visit and travel party/companion. These demographic factors have created their association to branding and market analysis, both for identifying market needs and demands and market segmentation.

Although there are numerous varieties of edible flowers available in the Philippines, there is a limited number of types of edible flowers being commonly used by restaurants.

Edible flowers are prone to insect or worm infestation due to the organic process of growing the plants. Digital marketing tools such as social media platforms, official websites and blogs/vlogs were the essential platforms that linked customers to restaurants, including the discovery of the products. Being unfamiliar with the edible flowers and unsure about flowers' edibility affected the customers' decision-making in trying or tasting a particular edible flower. Customers also showed high awareness, although limited to the gastronomic use of edible flowers in salads or as garnish.

Consumer behavior analysis plays an essential part in understanding how consumers think, expect and are being influenced before their actual purchase. Customers now rely on honest reviews regarding their actual experiences. They are sensitively influenced by what the reviews they see in the digital world, and they all significantly affect the purchasing decisions or patronage of customers. It is also important that customers are educated or oriented regarding our products the various means (can be channeled through marketing or advertising activities).

Customers have a significant common point of view when it comes to dining experiences. They value good customer relationship management, the physical environment or restaurant's theme, and the quality of the menu products being offered. Price has created a new value; affordability has not been part of the customer demands neither highlighted because they tend to focus on the value of branding, experience, and its impact on social status symbols. 
The majority of the demographic profiles of the customers have significant values and effects on the way, and process consumers behave. Age, the purpose of visit and travel party/companion, specifically, provide logical effect and importance. Those whose ages are in the millennials and generation $\mathrm{Z}$ brackets have been observed to spend more money eating out, and it is in this area where the value of restaurants is realized. Communal dining is also preferred by the majority of the target market due to their preference of traveling as a group or with friends.

Age has created a fine line defining the significant relationship between demographic profiles of customers and actual customer experiences. Age cohorts signify differences in expectations and experiences. Factors that compose consumer behavior have a mutual relationship or connection with customer experiences. Each factor significantly affects or depends on the actual dining experiences. The actual experiences are expected to be generated as the main source of influences, where the digital aid such as online reviews, which will later affect the purchasing decisions of a new customer (can be called the "first timers" or "prospective clients"). Today's generation has recorded a high dependence on searching products or services online or through mobile apps and make their decisions from their search results.

Amidst the growing market for edible flowers in the Philippines, the challenges or problems of restaurants offering edible flowers in their menus remain the same unless they are carefully and strategically addressed. Considering all the results and findings of this exploratory study on the gastronomic use of edible flowers in restaurants, including that of its potentially growing market, the researcher developed a strategic marketing framework that can help the sustainability of edible flowers in the Philippine contemporary menu offerings. The strategic marketing framework is presented through a table of specifications of the strategic components and is illustrated in a simplified restaurant marketing framework. Significant results of this study were collated to help the researcher come up with this marketing framework. The proposed marketing framework was originally created by the researcher by combining all the essential marketing factors and other elements that relatively showed impactful results in this study. The researcher arrived with her own marketing framework called D-I-C-E.

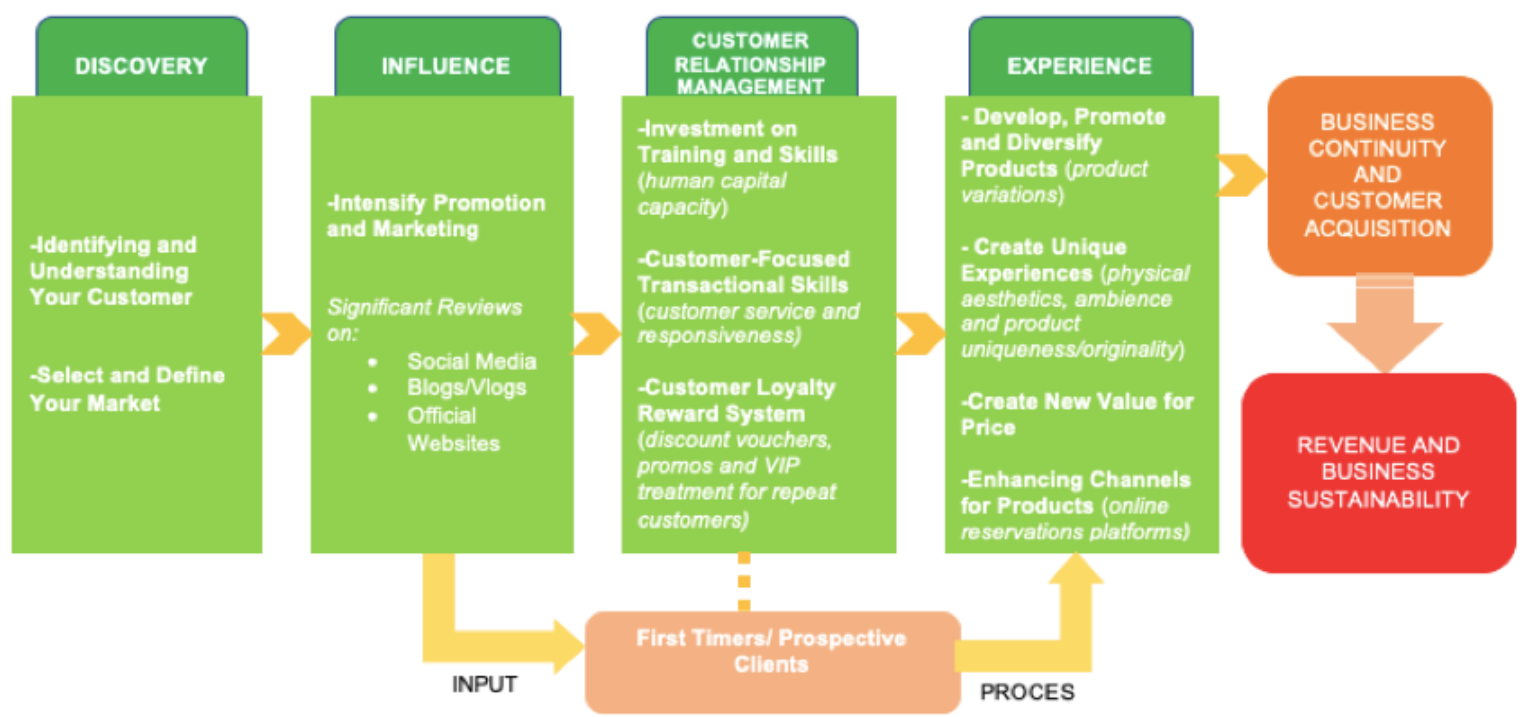




\section{REFERENCES}

Figure 2. D-I-C-E Proposed Restaurant Marketing Framework

Acutt, M. (2016). Concept of the Marketing Mix 4Ps by James Culliton 1948. https://marketingmix.co.uk/concept-of-the-marketing-mix-4ps/

Adams, R (2018). Edible Flowers May Be Your Next New Market: NCExtension. https://ipm.ces.ncsu.edu/2018/10/edible-flowers-may-be-your-next-new-market/

Agyekum, C. (2015). Consumer Perception of Product Quality. Scientific and Academic Publishing.

Alexander, L. (2015). 7 Modern Marketing Frameworks Every Startup Needs to Know. https://www.semrush.com/blog/7-modern-marketing-frameworks-every-startup-know/

Andrews, R. (2018). The Powerful Restaurant Marketing Framework (Free Visual Guide). https://restaurant.eatapp.co/blog/restaurant-marketing-framework

Black, C. (n.d.) The Master Gardeners: Edible Flowers- The New Rage in Haute Cuisine. https://www.emmitsburg.net/gardens/articles/adams/2012/edible_flowers.htm

Blackwell,M. et.al. (2001). Consumer Behaviour Theory: Approaches and Models. https://eprints.bournemouth.ac.uk/10107/1/Consumer_Behaviour_Theory_-

_Approaches_\%26_Models.pdf

Bernstein, R. (2018) Top Consumer Behavior Theories: Husson University. https://online.husson.edu/consumer-behavior-theories/

Bradshaw, A. (2018). Edible Flowers List With Flower Names and Pictures. https://commonsensehome.com/edible-flowers/

Breakfast with Flowers (n.d.) How to Use Edible Flowers. https://www.breakfastwithflowers.com/edible-flowers/

Chakraborty, P. (2017) 7 Important Factors That Influence the Buying Decision of a Consumer.https://www.linkedin.com/pulse/7-important-factors-influence-buying-decisionpallabi-chakraborty

$\begin{array}{llll}\text { Clem, } & \text { B. } & \text { (2008). } & \text { Butterfly }\end{array}$ https://keys.lucidcentral.org/keys/v3/pastures/Html/Butterfly_pea.htm

Davey, N. (2016). Infographic: How do preconceptions influence perceptions of social media content?. https://www.mycustomer.com/marketing/strategy/infographic-how-dopreconceptions-influence-perceptions-of-social-media-content

Degman, M. (2017). The History of Edible Flowers: Garden Guides. https://www.gardenguides.com/85738-history-edible-flowers.html

D'Antuono, L.F., Manco, M.A. (2013). Preliminary Sensory Evaluation of Edible Flowers From Wild Allium Species. Journal of the Science of Food and Agriculture 93(14/2018).

EconomicTimes (2016). Perceived Value Pricing. https://economictimes.indiatimes.com/p/perceived-value-pricing/articleshow/51807284.cms

Fernandes, L., Casal, S. et.al. (2019). An Overview on the Market of Edible Flowers. Food Reviews Internation Journal, 36(3/2020).

Gajic, T. et. al. (2015). The Linkage Between Traditional Food and Loyalty of Tourists to the Rural

Destinations. 
https://www.researchgate.net/publication/319376938_THE_LINKAGE_BETWEEN_TRADITIONA L_FOOD_AND_LOYALTY_OF_TOURISTS_TO_THE_RURAL_DESTINATIONS

Garcia, S. (2019). Sonya's Secret Garden. Cavite, PH: Tuwina and Poohpie Publishing.

Grygorczyk, A. (2018). Research indicates edible flowers are the top consumer food trend. https://www.freshplaza.com/article/2196439/research-indicates-edible-flowers-are-the-topconsumer-food-trend/

Hansen, J. (2017). Edible Flowers are on the rise. https://www.greenhousemag.com/article/floral-food/

Hanlon, A. (2019). Digital Marketing: Strategic Planning and Integration. UK: SAGE Publications.

Heshmat, S. (2017) 10 Factors That Influence Your Purchase Decisions. https://www.psychologytoday.com/us/blog/science-choice/201712/10-factors-influence-yourpurchase-decisions

iResearch Services (2018) . 5 Common Factors Influencing Consumer Behavior. https://www.iresearchservices.com/5-common-factors-influencing-consumer-behavior/

Juneja, P. (2019). Customer Relationship Management - Meaning, Need and Steps in CRM:

MSG Management Study Guide. https://www.managementstudyguide.com/customerrelationship-management.htm

Kelley, K. (2007). A Consumer's Guide to Edible Flowers. Retrieved from https://extension.psu.edu/a-consumers-guide-to-edible-flowers

Manson, L. (2018). 9 Effective Strategies for Restaurant Marketing. https://www.99dollarsocial.com/9-effective-strategies-for-restaurant-marketing/

Morgan, B. (2017). What us Customer Experience: Forbes. https://www.forbes.com/sites/blakemorgan/2017/04/20/what-is-customer-experience-

2/\#6907b5a170c2

Mealey, L. (2018). 10 Millenial Restaurant Dining Trends. https://www.thebalancesmb.com/millennial-restaurant-dining-trends-2888291

Pam (2011). Philippine Edible Flowers: Cooking Class. https://pamobieta.wordpress.com/2011/08/14/philippine-edible-flowers/

Pratap, A. (2019). Effect of Demographic Factors on Consumer Behavior: Age, Sex, Income and Education. https://notesmatic.com/2017/07/effect-of-demographic-factors-on-consumerbehavior-age-sex-income-and-education/

Rani, P. (2014). Factors Influencing Consumer Behaviour. EP Excellent Publisher 2(9/2014).

Raquel, PF., et. al. (2017). Edible Flowers: Knowledge and Consumption Habits. Acta Scientific Nutritional Health, 1(3/2017).

Simoni, N.K., Santos, F.F., et. al. (2017). The Use of Edible Flowers in Human Food Sensory Analysis of Preparations. Internation Journal of Food Engineering, 4(2/2018).

Tiwari,S. (2018). Latest Marketing Trends in Digital Media and Technology https://www.linkedin.com/pulse/latest-marketing-trends-digital-media-technology-year-tiwari

Wijaya, S. (2014). Encounters with local food: the culinary experiences of international visitors in Indonesia (Doctoral dissertation). HTTP:// vuir.vu.edu.au/id/eprint/25865 